\title{
農林漁業体験民宿の開業時における開業者の意向と特徵の分析
}

一規制緩和前と子ども農山漁村交流プロジェクト後を比較して一

\author{
坊 安恵 1$) *$ ・ 中村 貴子 1$)$
}

\section{Intentions and Features at the Time of Starting Farmer Inn Business: Comparing Before Deregulation and After the Children \& Agricultural Communities Interaction Project}

\author{
Yasue $\mathrm{Bo}^{1) *} \&$ Takako Nakamura ${ }^{1)}$
}

Recently, farmer inns have been increasing in many rural areas in Japan. We hypothesize that this could be due to their deregulation in 2003, and the Children \& Agricultural Communities Interaction Project (CACIP) in 2008. This study analyzes their intentions and features at the time of starting a farmer inn business, comparing before deregulation and after CACIP. The data analysis reveals the following: 1) Interaction of people is a prerequisite for starting a farmer inn. 2) The execution of various policies differs among an increase in farmer inns; those who started such a business before the deregulation simply wanted to gain economic advantage. On the other hand, those who started after CACIP and aimed at vitalization of their local communities and sympathized the experiencebased education tours is increased.

キーワード：農林漁業体験民宿, 規制緩和, 子ども農山漁村交流プロジェクト, 開業時の意向

\section{1. 研究目的亡背景}

グリーン・ッーリズム（以下，GT）は 1992 年に 政策用語として提唱されて以降, 日本各地で展開し ている. 1994 年には農山漁村滞在型余层活動のため の基盤整備の促進に関する法律（以下，農山漁村余 暇法）が制定された。本法律の第 2 条 5 に打いて 「農林漁業体験民宿とは，施設を設けて人を宿泊さ せ, 農林水産省令で定める農村滞在型余㗇活動又は 山村・漁村滞在型余暇活動に必要な役務を提供する 営業」と定義されている. 既にヨーロッパでは, 農 林漁業体験民宿が農林漁家の副収入源として位置づ けられ, 日本に先行して取り組まれていた 1 . しか し, 日本では, 宿泊業として営業するための法律「旅 館業法」による規制が厳しく、この規制をクリアす
るためには資金をかけた家屋の改修が必要であった (田平，2005：p. 54)。こうした事態を受けて，大分 県は 2002 年, 全国に先駆けて県独自の規制緩和に より，旅館業法に打ける簡易宿所の枠外にあった「民 泊」を合法的に「宿泊料」が受け取孔る取組とした (田平, $2005:$ p. 54 ; 中尾， 2008 : p. 187). 大分県 の動きや他の動きにも対応する形で, 2003 年以降, 農林漁業体験民宿の開業や運営に関わる各種法令の 規制緩和が段階的に全国で適用されている ${ }^{2}$. また, 2008 年には子どもたちの生きる力を育む学習の場ら くりとして, 子ども農山漁村交流プロジェクト（以 下，子ども農山漁村交流 PJ）が開始されている。 こ れは, 体験教育旅行 ${ }^{3}$ と呼ばれた。この取組では, 体験メニューの1つとして共同調理や宿泊体験を行

\footnotetext{
1) 京都府立大学大学院生命環境科学研究科; Graduate School of Life and Environmental Sciences, Kyoto Prefectural University 
らが，宿泊営業許可を必ずしも得ていない農家民 泊 4 と呼ばれる形態も混在する。 一方で, 一般旅行 者の受入事業をしたり，2016 年頃から増えてきたイ ンバウンド需要に対応したりするため, 多様な宿泊 希望者を受入れる取組は増やすべきと指摘されて打 り，そのための政策も展開されている ${ }^{5}$. 農林漁業 体験民宿を開業するためには，先述のような政策的 後押しは重要だが，農林漁業者の意向も重要だと考 えられる。

ここで，農林漁業体験民宿に関する先行研究をみ てみる。農林漁業体験民宿を含む農泊 ${ }^{6}$ の規制緩和 に関する研究には，中尾 $(2008,2009)$, 佐藤 (2010) による研究はあるが，これらは農家民宿の言葉の定 義や分類，またはその分類別にみた経営的視点から の研究である。一方, 体験教育旅行による農林漁業 体験民宿に関する研究には, 鈴村 (2009), 鈴村編 (2013), 佐藤 (2010), 若林（2015）による研究で みられるが, 子どもの学習効果に関する研究と地域 活性化に関する研究である. 農林漁業体験民宿開業 の要因については，坊・中村 (2013) が分析してい るものの，住民間ネットワークによる针誘実態から の解明に留まって抢り, 農林漁業体験民宿開業者の 意向からみた研究はみられない。

そこで本研究では, 2003 年に全国的に行わ机た大 幅な規制緩和前と 2008 年から開始した子ぞも農山 漁村交流 PJ 後を比較し, 農林漁業体験民宿を開業す る際の開業者の意向とその特徵を開業時期別に明ら かにすることを目的とする。な拉，農林漁業体験民 宿といら名称は農山漁村余暇法制定後の名称である が，厳密にい光ば，農山漁村余暇法の改正があった 2005 年以前は旅館業法の許可を得ていても非農家が 運営するものは農林漁業体験民宿といえなかった？ しかし改正後には, 1995 年から運用されていた農林 漁業体験民宿登録制度で，非農家でも要件を満たし た上で登録をすれば本名称の対象となった。ただし 本研究では，登録済みか否かではなく，非農家でも 登録できる要件を持つならば研究対象としている. すなわち開業時点では農林漁業体験民宿に分類でき なかったものでも, 調査時点で農林漁業体験民宿に 分類できる宿泊施設を本研究の研究対象とし, それ らを総じて農林漁業体験民宿と称する。 また, 地理 的な偏りを避けるため, 子ども農山漁村交流 PJ 事業
に掠いて分けられている全国 9 ブロック 8 の各ブロッ クに所属寸る対象地域の中から 1 所の地域を取り 上げ，その地域にある農林漁業体験民宿 30 世帯を対 象に，2015 年 8 月にアンケート調査を実施し，一部 の協議会と農林漁業体験民宿の開業者にヒアリング 調査を実施した。ただし，30世帯に満たない地域は その地域内の全農林漁業業体験民宿を対象とした。 アンケート調査の回収数は 114 世帯（58.8\%）であ り，有効回答数は 111 世帯（57.2\%）であった。い ずれの質問項目でも無回答者は分析の対象外々 した.

\section{2. 農林漁業体験民宿の開業実態の変遷}

\section{（1）宿泊施設としての要件}

農林漁業体験民宿の開業には，宿泊施設として主 に旅館業法，建築基準法，消防法，食事の提供には 食品衛生法等, 複数の法律要件を満たす必要がある。 通常, 空部屋を活用して小規模宿所を開業する場合, 簡易宿所営業許可の取得が必要だが，この際に障害 となるのは， $33 \mathrm{~m}^{2}$ 以上の客室延床面積，準耐火構 造の主要な間仕切壁の設置や宿泊室，廊下，階段等 の非常用照明装置の設置，消防用設備等の設置の要 件である。しかし， 2003 年に農林漁業者による農林 漁業体験が可能な宿所の開業に限り，旅館業法上の 面積要件が撤廃され， $33 \mathrm{~m}^{2}$ 未満の客室延床面積て も簡易宿所営業許可の取得が可能となった。以下， 順次行わ玌た規制緩和の内容は表 1 ，表 2 ，表 3 の 通りである.

\section{（2）統計からみた農林漁業体験民宿の開業推移}

規制緩和後の農林漁業体験民宿の新規開業数は, 農林水産省農村振興局の調べによると，2003 年は 140 件で，内，旅館業法の規制緩和利用（以下，内 数と表現する) が 108 件， 2004 年は 199 件で内数 180 件， 2005 年は 294 件で内数 270 件， 2006 年は 434 件で内数 402 件, 2007 年は 507 件で内数 493 件，2008 年は 357 件で内数 304 件，2009 年は 606 件で内数 597 件, 2010 年は 581 件で内数 573 件, 2011 年は 463 件で内数 458 件, 2012 年は 545 件て 内数 534 件となって打り，この 10 年間の平均は 412.6 件/年で内数 391.1 件/年である．以上ょり，農 林漁業体験民宿の新規開業数が増加していること, 新規開業数の $95.0 \%$ が規制緩和利用であることよ 
表 1. 農林漁業体験民宿での建築基準法の主な各種基準

\begin{tabular}{|c|c|c|c|}
\hline \multicolumn{2}{|l|}{ 区分 } & 規制緩和以前 & 規制緩和以後 \\
\hline \multicolumn{2}{|l|}{ 階段 } & 幅 $75 \mathrm{~cm}$ 以上, 蹴上 $22 \mathrm{~cm}$, 踏面 $21 \mathrm{~cm}$ 以上 & 蹴上 $23 \mathrm{~cm}$, 踏面 $15 \mathrm{~cm}$ 以上 \\
\hline \multicolumn{2}{|c|}{ 防火上主要な間仕切壁 } & $\begin{array}{l}\text { 旅館用途部分 : 間仕切壁は準耐火構造 } \\
\text { 小屋根又は天井裏 : 準耐火構造 }\end{array}$ & 適用なし \\
\hline \multicolumn{2}{|c|}{ 非常用の照明装置 } & 居室, 階段, 通路等に設置 & 適用なし \\
\hline \multirow{2}{*}{ 内装制限 } & 難燃材料等 & 難燃材料等 & 適用なし \\
\hline & 準不燃材 & 準不燃材 & 適用なし \\
\hline
\end{tabular}

資料 : 建築基準法（2018 年 8 月改正）に基づき筆者作成.

表 2. 農林漁業体験民宿での消防法上必要な主な措置基準

\begin{tabular}{|c|c|c|c|c|}
\hline \multicolumn{2}{|r|}{ 区分 } & 適用開始時期 & $\begin{array}{l}\text { 火災報知機の } \\
\text { 設置 }\end{array}$ & 消防法上必要な措置基準 \\
\hline \multicolumn{2}{|l|}{ 一般住宅 } & $\begin{array}{l}2006 \text { 年 } 6 \text { 月～ } \\
\text { 義務化 }\end{array}$ & $\begin{array}{l}\text { 住宅用火災報 } \\
\text { 知器 }\end{array}$ & - \\
\hline \multirow{4}{*}{$\begin{array}{l}\text { 農林漁業 } \\
\text { 体験民宿 }\end{array}$} & $\begin{array}{l}\text { 農林漁業体験民宿等の用途部分の } \\
\text { 床面積が } 50 \mathrm{~m}^{2} \text { 以下 } \\
\end{array}$ & \multirow{4}{*}{$\begin{array}{l}2004 \text { 年 } 1 \text { 月〜 } \\
\text { 消防長等の判断にて } \\
\text { 緩和措置あり }\end{array}$} & $\begin{array}{l}\text { 住宅用火災報 } \\
\text { 知器 } \\
\end{array}$ & - \\
\hline & $\begin{array}{l}\text { 農林漁業体験民宿等の用途部分の } \\
\text { 床面積が } 50 \mathrm{~m}^{2} \text { 以上 } \\
\Rightarrow \text { 旅館扱いなので，規制対象 }\end{array}$ & & \multirow[t]{2}{*}{$\begin{array}{l}\text { 特定小規模施 } \\
\text { 設用 }\end{array}$} & $\begin{array}{l}\text { (1)誘導灯, 誘導標識, 避難器具 } \\
\Rightarrow \text { 定の条件を満たす場合に限り, 消 } \\
\text { 防長等の判断にて設置を要しない. } \\
\text { (2)カーテン, 絨趒等は防炎物品の使用 }\end{array}$ \\
\hline & \begin{tabular}{|l} 
農家民宿等の用途部分の \\
面積が $150 \mathrm{~m}^{2}$ 以上 \\
\end{tabular} & & & \multirow{2}{*}{$\begin{array}{l}\text { 上記(1)，(2)に加えて(3)消火器または簡 } \\
\text { 易消火用具 }\end{array}$} \\
\hline & $\begin{array}{l}\text { 建物の床面積が } 300 \mathrm{~m}^{2} \\
\text { 以上 }\end{array}$ & & $\begin{array}{l}\text { 自動火㷋報知 } \\
\text { 設備 }\end{array}$ & \\
\hline
\end{tabular}

資料：消防法施行令及び附則（2017 年 3 月改正内容）に基づき筆者作成.

表 3. 農林漁業体験民宿での飲食物提供時における食品衛生法上の取扱

\begin{tabular}{c|l|l|l|l}
\hline \hline 時期 & 要請機関 & 要請先 & \multicolumn{1}{|c|}{ 飲食店営業許可の要否 } & \multicolumn{1}{c}{ 調理施設 } \\
\hline 2005 年以前 & - & - & 必要 (都道府県等の条例) & $\begin{array}{l}\text { 営業専用の調理施設等が } \\
\text { 必要 }\end{array}$ \\
\hline 2005 年 7 月 & $\begin{array}{l}\text { 厚生労働省 } \\
\text { 農林水産省 }\end{array}$ & 都道府県等 & $\begin{array}{l}\text { 管轄により不要 (条件 : } 1 \text { 回に提供する食事数や講習 } \\
\text { の䍃族兼用の調理場等の認可 }\end{array}$ \\
\hline 年 11 月 & 厚生労働省 & 都道府県等 & $\begin{array}{l}\text { 不要 (条件 : 提供される食事がすべて自炊, もしく } \\
\text { は共同調理の場合) }\end{array}$ & 家族兼用の調理場等の認可 \\
\hline
\end{tabular}

資料：農林水産省（2017）に基づき筆者作成.

り，規制緩和の効果はあったといってよいだろら。

一方で，規制緩和後の子ども農山漁村交流 PJ 前後 で新規開業者数の平均をみると, 子ども農山漁村交 流 PJ 前は 314.8 件/年で, 子ぞも農山漁村交流 PJ 後 は 510.4 件/年である。このことより，規制緩和導入 後で子ども農山漁村交流 PJ 後の新規開業者数及び 規制緩和利用率は相対的に子ども農山漁村交流 PJ 前に比べて増加していることが確認できた.

\section{3. 農林漁業体験民宿開業時の意向調査結果 （1）回答者の属性}

農林漁業体験民宿の経営主体者に行ったアンケー トの回答者の属性をみると，性別（N=108）は男性 が 44 世帯 $(40.7 \%)$ ，女性が 64 世帯（59.3\%）であ る。年代（N=108） は多い順に 60 歳代が 57 世帯 (52.8\%)， 70 歳代以上が 21 世帯（19.4\%)，50 歳代 が 13 世帯 (12.0\%), 30 歳代以下が 10 世帯 (9.3\%), 
40 歳代が 7 世帯（6.5\%） であり，60 歳代以上の経 営者が $72.2 \%$ 占めている.

同居家族世代数（N=104）は 1 世代が 44 世帯 (42.3\%)，2 世代が 39 世帯 $(37.5 \%), 3$ 世代以上が 21 世帯（20.2\%）である。また，家庭内での受入体 制（N=108）は夫婦での受入が 66 世帯 $(61.1 \%)$, 家族全員での受入が 23 世帯 $(21.3 \%)$ であり， 1 世 代の夫婦が 2 人で受入れているのは 39 世帯で, 2 世 代以上の家族全員で受入れている 23 世帯の合計は 62 世帯（57.4\%）である。以上より，農林漁業体験 民宿の経営は同居家族全員での協力が重要と考兄ら れた。

また，農林漁業体験民宿の開業時期（ $\mathrm{N}=99 ）$ は 規制緩和以前が 24 世帯 (24.2\%)，規制緩和以降か つ子ぞも農山漁村交流 PJ 開始以前は 5 世帯 (5.1\%), 子ども農山漁村交流 PJ 開始以降は 70 世帯 （70.7\%）であり，子ぞも農山漁村交流 PJ 後に開業 した農林漁業体験民宿が多いことが確認できた，本 研究では，全体の意向を把握する際には全回答者を 対象とし，規制緩和前と子ぞも農山漁村交流 PJ 後を 比較する際には規制緩和前に開業した 24 世帯と規 制緩和及び子ども農山漁村交流 PJ 後に開業した 70 世帯を対象としている.

\section{(2) 開業目的の特徵}

農林漁業体験民宿の開業目的を順位付け形式で 3 つまで尋ねた（表 4)，最も多いのは，「来訪者との 交流を楽しむため」が 67 世帯 (61.5\%)，続いて， 「農業・農村への理解拡大」が 45 世帯 (41.3\%), 「所 得の向上」が 42 世帯 $(38.5 \%)$,「都市との交流によ る農村活性化」が 41 世帯（37.6\%）であった。「来 訪者との交流を楽しむため」や「都市との交流によ る農村活性化」という「交流」を目的に開業した世 帯は全経営世帯の 89 世帯 $(81.7 \%)$ であり，汪とん ぞの農林漁業体験民宿ではなんらかの交流を重視し ていることが明らかとなった．

続いて，各回答者が特に意識している点と考兄ら れる 1 位の回答をみる。「来訪者との交流を楽しむた め」が 33.0\% と突出して和り，「所得の向上」 $15.6 \%$, 「都市との交流による農村活性化」 $14.7 \%$, 「地域内 の観光業振興」 $13.8 \%$ と続く.

これらの結果から，交流が開業目的として高いこ とはわかるが，全体の $41.3 \%$ 㗳した「農業・農
表 4. 開業目的（上位 3 位までの順位付け形式）

\begin{tabular}{l|r|r|r}
\hline \multirow{2}{*}{ カテゴリ } & \multicolumn{2}{|c|}{ 全体 2 } & \multicolumn{1}{c}{ 1位 } \\
\cline { 2 - 4 } & 件数 & 構成比 & 構成比 \\
\hline 来訪者との交流を楽しむため & 67 & 61.5 & 33.0 \\
\hline 農業・農村への理解の拡大 & 45 & 41.3 & 11.9 \\
\hline 所得の向上 & 42 & 38.5 & 15.6 \\
\hline 都市との交流による農村活性化 & 41 & 37.6 & 14.7 \\
\hline 地域を知ってもららため & 34 & 31.2 & 1.8 \\
\hline 地域内の観光業振興 & 30 & 27.5 & 13.8 \\
\hline 受入の依頼に応えるため & 29 & 26.6 & 4.6 \\
\hline 都市農村交流人口の増加 & 16 & 14.7 & 2.8 \\
\hline 定住人口の維持・増加 & 7 & 6.4 & 0.9 \\
\hline その他 & 3 & 2.8 & 0.9 \\
\hline 合計 & 109 & 100 & 100 \\
\hline
\end{tabular}

資料: アンケート調査に基づき筆者作成. 以下，同様である. 1）件数の単位は世帯，構成比の単位は\%である.

2）全体とは， 3 個までの複数回答である. 以下, 表 5 も同 様である.

村への理解の拡大」の 1 位の回答は $11.9 \%$ と 5 番目 であり，農業・農村への理解は農林漁業体験民宿者 にとって意識する項目ではあるが，強く意識する項 目とはいえないと考兄られた。むしろ，全体では $27.5 \%$ しか回答していない「地域内の観光業振興」 の 1 位の回答は $13.8 \%$ と全体の回答割合は少数では あるが，観光への思いを持つ回答者は観光分野への 貢献を強く意識していることが示唆された。「所得の 向上」は全体でも 1 位の回答でも 3 番目であり, こ れも交流と同様，幅広い層に支持されている開業目 的であることがわかった，以上から，農林漁業体験 民宿の開業者の意向としては「交流」といら主目的 に加え, 経済的要素である「観光業振興」や「所得」 につなげる取組と認識して開業する者が多いと考え られた。

\section{（3）開業時期別にみた開業目的の特徵}

次に, 規制緩和及び子ども農山漁村交流 PJ が農林 漁業体験民宿の開業意向に変化を生じさせているの かをみるため，開業時期別にみる，上位 3 位までの 複数回答である全体では，規制緩和前は「所得の向 上」と「地域内の観光業振興」に，子ぞも農山漁村 交流 PJ 後は「農業・農村への理解の拡大」にそれぞ れ特徵がみられた（表 5 )。また，1位の回答では， 規制緩和前は「所得の向上」と「地域内の観光業振 
表 5. 開業時期別にみた開業目的（上位 3 位までの順位付け形式，単位：\%)

\begin{tabular}{|c|c|c|c|c|c|c|c|c|c|c|c|}
\hline & & $\begin{array}{c}\text { 来訪者 } \\
\text { との交流 } \\
\text { を楽しむ } \\
\text { ため }\end{array}$ & $\begin{array}{l}\text { 農業・農 } \\
\text { 村への理 } \\
\text { 解の拡大 }\end{array}$ & $\begin{array}{c}\text { 所得の } \\
\text { 向上 }\end{array}$ & $\begin{array}{c}\text { 都市との } \\
\text { 交流によ } \\
\text { る農村 } \\
\text { 活性化 }\end{array}$ & $\begin{array}{l}\text { 地域を } \\
\text { 知っても } \\
ら ら た め ~\end{array}$ & $\begin{array}{l}\text { 地域内 } \\
\text { の観光 } \\
\text { 業振興 }\end{array}$ & $\begin{array}{c}\text { 受入依 } \\
\text { 頼に応え } \\
\text { るため }\end{array}$ & $\begin{array}{c}\text { 都市農 } \\
\text { 村交流 } \\
\text { 人口の } \\
\text { 増加 }\end{array}$ & $\begin{array}{c}\text { 定住人 } \\
\text { 口の維 } \\
\text { 持・増加 }\end{array}$ & 合計 \\
\hline \multirow{4}{*}{ 全体 } & 全体 $(\mathrm{N}=92)$ & 60.9 & 41.3 & 39.1 & 34.8 & 32.6 & 29.3 & 29.3 & 15.2 & 5.4 & 100 \\
\hline & 前 2$)(\mathrm{N}=23)$ & 52.2 & 13.0 & 73.9 & 17.4 & 34.8 & 47.8 & 30.4 & 4.3 & 4.3 & 100 \\
\hline & 後 2) $(\mathrm{N}=69)$ & 63.8 & 50.7 & 27.5 & 40.6 & 31.9 & 23.2 & 29.0 & 18.8 & 5.8 & 100 \\
\hline & 有意差 & & $* *$ & $* * *$ & & & $* *$ & & & & \\
\hline \multirow{4}{*}{1 位 } & 全体 $(\mathrm{N}=92)$ & 33.7 & 10.9 & 16.3 & 15.2 & 1.1 & 14.1 & 5.4 & 1.1 & 1.1 & 100 \\
\hline & 前 2$)(\mathrm{N}=23)$ & 17.4 & 4.3 & 47.8 & 0 & 0 & 30.4 & 0 & 0 & 0 & 100 \\
\hline & 後 2) $(\mathrm{N}=69)$ & 39.1 & 13.0 & 5.8 & 20.3 & 1.4 & 8.7 & 7.2 & 1.4 & 1.4 & 100 \\
\hline & 有意差 & $*$ & & $* * *$ & $* *$ & & $* *$ & & & & \\
\hline
\end{tabular}

1）カイ二乗検定後，各項目に执いて残差分析を行い，有意差がみられた場合，1，5，10\%の有意水準各々に***，**，*を 示している. 以下，表 6,7 も同様である.

2)「前」は規制緩和前の 2002 年以前，「後」は子ども農山漁村交流 PJ 後の 2008 年以降を示し，無回答は含まない。以下， 表 6,7 も同様である.

興」に，子ども農山漁村交流 PJ 後は「来訪者との交 流を楽しむため」と「都市との交流による農村活性 化」にそれぞれ特徵がみられた。規制緩和前に該当 するモニタ一地域には，GT の提唱以前から農閑期 の冬期にスキー客をターゲットとした観光業による 農外所得の確保を目的とした副業的な民宿経営を 行っている地域子含まれており, 農閑期の農外所得 の獲得と地域内の観光業振興を目指す受入地域づく りが行われ, 受入世帯確保の勧誘が行われていたス キ一民宿転換型の経緯と合致する ${ }^{9}$. そのため，開 業に必要な煩雑な申請手続きや高額な改修工事費用 に関する負担をしてでも開業することが可能であっ たと考兄られる。しい，規制緩和後は，開業に打 ける改修工事費の負担が軽減されたこともあり, 子 ぞも農山漁村交流 PJ 後は, 「所得の向上」といら直 接的経済効果よりも非経済的効果である「農業・農 村への理解拡大」につながる教育や文化継承等, 農 業・農村が有する多面的機能を発揮するものとして 農林漁業体験民宿が認識されたことで,「来訪者との 交流を楽しむため」や「都市との交流による農村活 性化」といら「交流」の手段として活用されたもの と考兄られる。また，このことは子ども農山漁村交 流 PJ の事業目的でもあり, 子ども農山漁村交流 PJ 後に非経済的効果に当たる農林漁業体験民宿の開業 目的への理解が䁔成されたことで，農林漁業体験民 宿の増加につながったと考光られる。

\section{（4）開業経緯の特徵}

続いて，農林漁業体験民宿の開業経緯をみると， 表 6 より勧誘による開業が 68 世帯 $(64.2 \%)$ ，自発 的な開業が 38 世帯（35.8\%）となって拈り，勧誘に よる開業が多いといえる.

開業時期別にみると，規制緩和前は「自発的な開 業」と「行政からの勧誘による開業」と「他の農林 漁業体験民宿経営者からの勧誘による開業」に，子 ども農山漁村交流 PJ 後は「コーディネート組織から の勧誘による開業」に特徵がみられた。ここで，コー ディネート組織による勧誘 27 世帯のらち $81.5 \%$ に 当たる 22 世帯が規制緩和後に当たる 2008 年の子ぞ も農山漁村交流 PJ 後に開業している。つまり，規制 緩和前は所得向上という直接的経済効果に賛同し た，自らの意思による自発的な開業であるため，規 制緩和に依拠しない開業となっており，開業の主要 因は直接的経済効果を期待するものであるといえる. 一方で，規制緩和後は GT による地域活性化策の導 入・展開を行ら上で，規制緩和を活用した受入地域 づくりを取り組み始めたことに加えて，2008 年から 開始した子ぞも農山漁村交流 PJ の受入地域づくり の体制整備による開業がコーディネート組織や行政 等から促進されていたことを踏まえると，子ども農 山漁村交流 PJ の目的への共感が開業要因として重 要であったと考觉られる。 
表 6. 開業時期別にみた開業経緯（単位：\%）

\begin{tabular}{|c|c|c|c|c|c|c|c|c|c|}
\hline & & $\begin{array}{c}\text { 自発的に } \\
\text { 開業 }\end{array}$ & $\begin{array}{c}\text { 勧誘により } \\
\text { 開業 }\end{array}$ & $\begin{array}{c}\text { コーディ } \\
\text { ネート組織 }\end{array}$ & $\begin{array}{c}\text { 他の農林漁 } \\
\text { 業体験民宿 } \\
\text { 経営者 }\end{array}$ & 行政 & 知人 & 未選択 & 合計 \\
\hline \multicolumn{2}{|c|}{ 全体（N=106） } & 35.8 & 64.2 & 25.5 & 0.9 & 5.7 & 1.9 & 30.2 & 100 \\
\hline \multirow{4}{*}{$\begin{array}{l}\text { 開業 } \\
\text { 時期 }\end{array}$} & 全体 $(\mathrm{N}=91)$ & 34.1 & 65.9 & 26.4 & 1.1 & 5.5 & 2.2 & 30.8 & 100 \\
\hline & 前 $(\mathrm{N}=23)$ & 56.5 & 43.5 & 8.7 & 4.3 & 13.0 & 0 & 17.4 & 100 \\
\hline & 後 $(\mathrm{N}=68)$ & 26.5 & 73.5 & 32.4 & 0 & 2.9 & 2.9 & 35.3 & 100 \\
\hline & 有意差 & $* * *$ & $* * *$ & $* *$ & $*$ & $*$ & & & \\
\hline
\end{tabular}

1）全体（N=106） は調查対象世帯全体，全体（N=91）は開業時期の規制緩和前と子ぞも農山漁村交流 PJ 後に開業した世 帯が該当する. 以下，表 7 も同様である.

表 7. 開業時期別にみた開業時の苦労点（単位：\%)

\begin{tabular}{|c|c|c|c|c|c|c|c|c|c|c|c|}
\hline & & $\begin{array}{l}\text { 行政機関 } \\
\text { での申請 }\end{array}$ & $\begin{array}{l}\text { 行政 } \\
\text { 空口 }\end{array}$ & 保健所 & 消防署 & $\begin{array}{c}\text { 家族・ } \\
\text { 近所の } \\
\text { 同意 }\end{array}$ & $\begin{array}{c}\text { 食事メ } \\
\text { ニュー・ } \\
\text { 献立の } \\
\text { 考案 }\end{array}$ & $\begin{array}{c}\text { 交流・体 } \\
\text { 験メ } \\
=ュ-9 \\
\text { 考案 }\end{array}$ & $\begin{array}{c}\text { 衛生・ } \\
\text { 事故等の } \\
\text { 安全管理 }\end{array}$ & $\begin{array}{l}\text { 特に } \\
\text { ない }\end{array}$ & 合計 \\
\hline \multicolumn{2}{|c|}{ 全体（N=102） } & 30.4 & 9.8 & 24.5 & 20.6 & 9.8 & 20.6 & 23.5 & 25.5 & 49.0 & 100 \\
\hline \multirow{4}{*}{$\begin{array}{l}\text { 開業 } \\
\text { 時期 }\end{array}$} & 全体（N=85） & 35.3 & 10.6 & 28.2 & 23.5 & 10.6 & 20.0 & 23.5 & 25.9 & 47.1 & 100 \\
\hline & 前 $(\mathrm{N}=21)$ & 71.4 & 23.8 & 61.9 & 71.4 & 9.5 & 23.8 & 28.6 & 38.1 & 9.5 & 100 \\
\hline & 後（N=64） & 23.4 & 6.3 & 17.2 & 7.8 & 10.9 & 18.8 & 21.9 & 21.9 & 59.4 & 100 \\
\hline & 有意差 & $* * *$ & & $* *$ & $* * *$ & & & & & $* * *$ & \\
\hline
\end{tabular}

\section{（5）苦労点の特徵}

農林漁業体験民宿開業時の苦労点を複数回答で尋 齐たところ，「特にない」が 50 世帯 $(49.0 \%)$ と最 も多く, 続いて「行政機関での申請」が 31 世帯 (30.4\%), 「衛生・事故等の安全管理」が 26 世帯 (25.5\%) である（表 7)、「特にない」ではコーディ ネート組織（27 世帯，26.5\%) や行政（21 世帯， 20.6\%）の協力によるものと回答して扣り，農林漁 業体験民宿開業時にコーディネート組織や行政が開 業者に係る苦労を軽減していることが考えられる. また，「行政機関での申請」では保健所（25世帯， $24.5 \%$ ), 消防署（21世帯，20.6\%）での申請に苦労 していることが確認できた. 主な苦労点は「申請に 関する自身の知識不足」,「度重なる申請書類作成や 提出」, 「家の見取り図作成」, 「飲食店営業許可の要 件を満たす準備」である。 また，「下見をせず，高額 な設備設置の強制」,「管轄行政内第 1 号の申請, か つ，行政の担当者が不在であったため，たらいまわ しになった」という声もあった。農林漁業体験民宿 開業時に, 行政での不慣秃な申請プロセスや申請基
準に苦労している世帯の存在が明らかとなった。ま た，行政の不手際により行政機関での申請に苦労し ている世帯の存在が一部確認された.

開業時期別にみると，規制緩和前は「保健所と消 防署である行政機関での申請」に，子ども農山漁村 交流 PJ 後は「特にない」にそれぞれ特徴がみられ る. 行政機関での農林漁業体験民宿開業に係る申請 では，従来，膨大な書類等の手続きや開業基準を満 たす家屋の改修工事等が必要であったが，規制緩和 後は，必要最小限の諸手続きや改修工事等で開業が 可能になったことにより，申請時の苦労は軽減した ことがヒアリング調査より確認できた。他方で，先 駆者の手続きやその他苦労点がコーディネート組織 に蓄積され，マニュアル化され，勉強会等により後 続開業者に伝達されていることも併せて確認できた。 子ども農山漁村交流 PJ 後は交流に意欲的な開業者 をフォローするコーディネート組織の役割が大きい ことが示唆され, 農林漁業体験民宿の増加につながっ たと考えられる。 


\section{4. 農林漁業体験民宿開業時の特徵の分析}

農林漁業体験民宿開業時の特徵を整理すると, 交 流への関心がある人でなければ開業には向かわない だろらと考えられた。規制緩和前と子ども農山漁村 交流 PJ 後を比較した結果, 規制緩和前は所得の向上 や地域内の観光業振興等, 直接的経済効果を期待す る人の割合が多く, 自発的に開業する人の割合が多 かった. その一方で, 子ども農山漁村交流 PJ 後は直 接的経済効果よりもむしろ, 農業・農村への理解の 拡大, 来訪者との交流を楽しむためや都市との交流 による農村活性化等, 非経済的効果を期待する人の 割合が多く，受動的に勧誘を受ける人の割合が多 かった。 また, 農林漁業体験民宿の開業数の増加率 の伸びは, 子ども農山漁村交流 PJ 後より規制緩和後 の方が高く, 規制緩和を利用した農林漁業体験民宿 の開業が子ども農山漁村交流 PJ 後は更に増加して いた，加えて，ヒアリング調査より，その背景には 規制緩和があったことだけでなくマニュアル等先駆 者の経験が関係していることも明らかとなった．法 的規制緩和といら公的条件と子ども農山漁村交流 PJ といらンフト事業的政策条件の両方がなくては, 開 業数は増えなかったということが本結果から考えら れる。

また, 開業時の個人の関心といら点では, 交流が 一番ではあるものの, 観光業振興への貢献や所得の 増加への関心も高く, その割合は規制緩和前に開業 している人で多かった. 1 つの地域に受入農林漁業 体験民宿数が複数あることで, 地域の観光業として の GTは盛り上がるだろら。そう考えると, 子ぞも 農山漁村交流 PJ の取組は GT 事業の発展といら地 域経済活動のために必要な存在だったといえる。ま た, 同業者という仲間を増やすためにも, 子ども農 山漁村交流 PJ の取組後に勧誘されて開業したという 人が多かったことから, 子ども農山漁村交流 PJ の取 組は勧誘しやすい取組みだったと考兄られ，子ども 農山漁村交流 PJ の取組が結果として地域の活性化 につながったと考えられた.

また, 開業時の苦労点に対する評価について, 規 制緩和前は保健所と消防署への申請が大変であると いら回答が有意に高いが, 子ども農山漁村交流 PJ 後 は「苦労点は特になし」で有意に高い結果が得られ た。つまり，初期の開業に抢ける「行政機関での申
請」の苦労点は，ノウハウとして蓄積され，マニュ アル作成や農林漁業体験民宿の勉強会に活かされ た。この研修等を実施するコーディネート組織の確 立も農林漁業体験民宿の開業には必要な条件とい兄 よう.

以上のことから, 規制緩和によって農林漁業体験 民宿の開業の手続きが簡素化されたといらことに加 え，子ども農山漁村交流 PJ 事業，交流，観光業によ る農村の経済活性化が農林漁業体験民宿開業者数増 加のインセンティブになっていることが示唆された. また，コーディネート組織の存在，開業マニュアル の存在も農林漁業体験民宿数増加のインセンティブ になっていることが示唆された。

\section{謝辞}

本稿は農林水産省の平成 27 年度都市農村共生・対 流総合対策交付金事業により行った調査に基づいて 作成している。

\section{注}

1 山崎他（1993：pp. 18-24）によると, ヨーロッパ大陸で GT の議論が先行される中, 後発として 1980 年代後半, イギリ スに拈いても議論されるようになった，イギリスでは，農村 地域での雇用機会及び所得の大幅な減少が問題となって拉 り，成熟化したッーリズムを GT に発展させ，農家なぞの経 営の多角化に上る安定化や農村地域の社会・経済構造の大き な変容の回避を図られていた。この経営の多角化の 1 つに農 林漁業体験民宿があるとされている.

2 農林水産省 (2017) を参照.

3 鈴村（2009：p. 41）によれば，小中学生を対象とした農家民 泊を含む一連の農林漁業体験プログラムを「農林漁業体験教 育旅行 $=$ 体験教育旅行」と略称している.

4 農家民泊とは, 各都道府県独自のガイドラインにて体験教育 旅行に限り, 限定的に許容されたものであり, 旅館業法上の 営業許可を取得していない.

5 農林水産省（2018）によると, 都市農村交流の取組に抢いて 持続的な産業とするために法人格を持った推進組織の運営を 自立させることを課題とし，2017 年度に 205 地域，2018 年 度に 147 地域の全国計 352 地域で農泊を推進するための事業 を展開している.

6 農泊とは, 農山漁村に扔いて日本ならではの伝統的な生活体 験と農村地域の人々との交流を楽しみ，農家民宿，古民家を 活用した宿泊施設など，多様な宿泊手段により旅行者にその 土地の魅力を味わってもらら農山漁村滞在型旅行を指すと定 義され, 現在, 農林水産省ではこの「農泊」を使用して打 
り，本稿でもこの意味で用いる.

72005 年の農山漁村余暇法の改正により, 本法律の対象者が 「農林漁業者またはその組織する団体」から「農林漁業体験 活動等のサービスを提供できる一般の宿泊業者」と変更され た.

8 総務省・文部科学省・農林水産省・環境省の 4 省で設置する 子ども農山漁村交流 PJ 推進委員会は全国を北海道, 東北, 関東, 東海, 北陸, 近畿, 中国・四国, 九州, 沖縄の 9 ブ ロックに分けている. なお, 2019 年現在, この委員会は活動 していない.

9 佐藤（2010：pp. 102）飞扔いて，「スキ一民宿からの『転換』 といってもスキー部門がまったくなくなったわけではない. 閑散期に打ける GT 部門の追加であり, 経営部門の拡大, 多 角化，新分野への進出を意味する，その度合いは民宿によっ て異なっているが，(中略)，いまだスキ一部門が経営の中心 にある民宿がほとんどである」と述べて括り, 本稿でも佐藤 の定義を用いる.

\section{引用文献}

佐藤真弓（2010）『都市農村交流々学校教育』農林統計出版. 鈴村源太郎（2009）「小中学生の体験教育旅行受け入れによる 農村地域活性化」『農林水産政策研究』第 15 号 : 41-59. 鈴村源太郎編著（2013）『農山漁村宿泊体験で 子どもが変わ
る 地域が変わる』農林統計協会.

田平厚子（2005）「観光まちづくりの地域内普及要素と持続性 一安心院町の GT による地域振興一」『総合観光研究』4: 53-64.

中尾誠二（2008）「農林漁家民宿に係る規制緩和と民泊の位置 付けに関する一考察」『2008 年度日本農業経済学会論文 集』: 186-193.

中尾誠二（2009）「規制緩和型農林漁家民宿に関する一考察 『2009 年度日本農業経済学会論文集』: 386-393.

農林水産省（2017）「農家民宿関係の規制緩和」, http:// www.maff.go.jp/j/nousin/kouryu/attach/pdf/170203-3.pdf (2019 年 9 月 30 日参照).

農林水産省（2018）「農泊推進の現状と課題について」, https:// www.maff.go.jp/j/nousin/kouryu/nouhaku/attach/pdf/ arikata-1.pdf (2020 年 3 月 21 日参照).

坊 安恵 - 中村貴子（2013）「体験教育旅行に打忊る受入農家 民泊の普及に関する研究」『農林業問題研究』49(2) : 157162. https://doi.org/10.7310/arfe.49.409.

山崎光博・小山善彦・大島順子 (1993)『グリーン・ッーリズ ム』家の光協会.

若林憲子（2015）「グリーンッーリズムの教育旅行による農家 民宿・農家民泊受入と農業・農村の展開の可能性」『地域 政策研究』15(3) : 159-179. 